\title{
Społeczno-demograficzne i rodzinne uwarunkowania pierwszych doświadczeń seksualnych i inicjacji seksualnej młodzieży
}

\author{
Zbigniew Izdebski ${ }^{1}$, Krzysztof Wąż ${ }^{2}$, Joanna Mazur ${ }^{3}$, \\ Anna Kowalewska ${ }^{4}$
}

\begin{abstract}
${ }^{1}$ Katedra Biomedycznych Podstaw Rozwoju i Seksuologii, Wydział Pedagogiczny, Uniwersytet Warszawski, Warszawa; ${ }^{2}$ Katedra Seksuologii, Poradnictwa i Resocjalizacji, Wydział Pedagogiki, Psychologii i Socjologii, Uniwersytet Zielonogórski, Zielona Góra; ${ }^{3}$ Zakład Zdrowia Dzieci i Młodzieży, Instytut Matki i Dziecka w Warszawie, Warszawa;

${ }^{4}$ Katedra Biomedycznych Podstaw Rozwoju i Seksuologii, Wydział Pedagogiczny, Uniwersytet Warszawski, Warszawa

Adres do korespondencji: Zbigniew Izdebski, Katedra Biomedycznych Podstaw Rozwoju i Seksuologii, Wydział Pedagogiczny, Uniwersytet Warszawski, 00-561 Warszawa, ul. Mokotowska 16/20, tel. 2255308 00, z.izdebski@ ips.uz.zgora.pl
\end{abstract}

\section{Abstract}

\section{Socio-demographic and familial determinants of first sexual experiences and sexual initiation of young people}

The study analyses the relationship of selected socio-demographic characteristics of adolescents (gender, place of residence, type of school) and selected characteristics of their families (education of parents, family wealth, support and communication) with their pre-initiation sexual experiences and sexual initiation. The results of a research carried out on a sample of 1,266 second-and third-class students of post-secondary schools have been analysed. The survey used an auditorium questionnaire. It has been shown that: three-fifths of the respondents had sexual experiences, of whom two-fifths already had sexual intercourse; girls were less likely than boys to have had sexual initiation, but more often than they got involved into pre-initiation forms of sexual activity; people who had a sexual initiation got involved into early forms of sexual activity earlier than those who didn't have it yet. Factors that differentiate young people's sexual behaviour have also included: the type of school, family support and material resources of the family. It has been established that in the case of boys, the risk factor for early sexual initiation is low family support and high level of affluence, while the protective factor is attendance at general secondary school or technical secondary school, and in the girls' group, the protective factor is attendance at general secondary school, while the risk factor is living in a large city.

Key words: sexual activity, sexual initiation, adolescents, sexual and reproductive health

Stowa kluczowe: antykoncepcja, dzietność, plany prokreacyine, zdrowie reprodukcyjne

\section{Wstẹp}

Problematyka zdrowia młodzieży najczęściej omawiana jest w aspekcie rozwojowym i w kontekście podejmowania przez nastolatków zachowań ryzykownych [1]. W okresie adolescencji bardzo ważną składową rozwoju jest rozwój psychoseksualny [2]. Z tego powodu ważne jest podejmowanie badań i analiz poświęconych zdrowiu seksualnemu i prokreacyjnemu młodzieży, tym bardziej że w okresie ostatniego dwudziestolecia nastąpiły znaczące zmiany w zachowaniach seksualnych młodzieży i ich uwarunkowaniach [3].

Jak podkreśla Magdalena Sokołowska, kryteria zdrowia mają charakter historyczny, zmieniają się wraz 
z sytuacją społeczną, warunkami środowiskowymi, normami i zwyczajami określonych zbiorowości społecznych, aktualnym etapem rozwoju człowieka [4]. Zważywszy na tematykę niniejszego artykułu, konieczne jest odniesienie się do definicji zdrowia reprodukcyjnego, które oznacza, że ludzie są w stanie prowadzić satysfakcjonujące i bezpieczne życie seksualne, płodzić dzieci oraz w sposób swobodny decydować o ich liczbie i czasie ich poczęcia [5]. Rozpatrując zdrowie reprodukcyjne w odniesieniu do młodzieży, konieczne jest uwzględnienie perspektywy rozwojowej, w tym rozwoju psychoseksualnego oraz fizycznego, emocjonalnego, społecznego i moralnego. W Karcie Praw Seksualnych i Reprodukcyjnych Międzynarodowej Federacji Planowania Rodziny (IPPF) zdrowie seksualne i reprodukcyjne młodzieży, to jest osób poniżej 25. roku życia, zdefiniowano jako fizyczny i emocjonalny dobrostan, polegający na byciu zdrowym i wolnym od zbyt wczesnej i niepożądanej ciąży, niebezpiecznej aborcji, infekcji przenoszonych drogą płciową, w tym HIV/AIDS, jak również przemocy seksualnej i przymusu [6]. W tym kontekście pierwszoplanowy staje się problem podejmowania aktywności seksualnej przez młodzież. Problem normatywności aktywności seksualnej w odniesieniu do nastolatków jest złożony. Według Marii Beisert w przypadku młodzieży możemy mówić o aktywności seksualnej mieszczącej się w granicach normy rozwojowej, jeśli: nie utrudnia realizacji zadań rozwojowych przewidzianych dla tego okresu; mieści się w repertuarze zachowań seksualnych charakterystycznych dla danego wieku; dokonuje się między osobami będącymi w zbliżonym wieku; oparta jest na zasadzie dobrowolności; prowadzi do realizacji celów seksualnych; nie narusza zdrowia; nie narusza rażąco przyjętego porządku społecznego [7].

Ponieważ uzyskiwanie doświadczeń seksualnych wynika z prawidłowości okresu dorastania, jest niezbędnym elementem procesu uspołeczniania seksualności, podlega swoistemu „moratorium” ze strony dorosłych [8]. Jednak względy światopoglądowe, kulturowe oraz obawa o liczne negatywne konsekwencje mogące mieć miejsce w przypadku zbyt wczesnego podejmowania aktywności seksualnej, a zwłaszcza inicjacji seksualnej, powodują, że ta sfera funkcjonowania młodzieży jest poddawana dużej presji obyczajowej.

Możemy mówić o licznych uwarunkowaniach aktywności seksualnej młodzieży. Problem ten był przedmiotem wielu badań, zwłaszcza w odniesieniu do inicjacji seksualnej [9]. Do najbardziej istotnych uwarunkowań wczesnego podejmowania aktywności seksualnej należą płeć, kontekst rodzinny i jego cechy, oddziaływania społeczno-kulturowe, w tym obecność i jakość edukacji seksualnej w szkole, stosunek do wiary oraz czynniki biologiczne (takie jak tempo rozwoju psychoseksualnego).

Niniejsze opracowanie jest poświęcone związkom między czynnikami społeczno-demograficznymi i relacjami rodzinnymi a pierwszymi, przedinicjacyjnymi doświadczeniami seksualnymi i inicjacją seksualną podejmowaną przez młodzież.

\section{Aktywność seksualna młodzieży, jej specyfika i uwarunkowania}

Rozwój seksualny człowieka trwa przez całe życie [10]. Wpływ na niego mają zarówno czynniki genetyczne, procesy fizjologiczne zachodzące $\mathrm{w}$ organizmie człowieka, jak i czynniki emocjonalne, poznawcze, behawioralne. Człowiek jako istota społeczna w całym swoim życiu podlega również silnie wpływowi czynników społecznych i kulturowych. Z tego powodu rozwój seksualny człowieka należy postrzegać holistycznie z uwzględnieniem różnych sfer rozwoju. W literaturze przedmiotu opisuje się go jako rozwój psychoseksualny.

Przebieg dojrzewania seksualnego jest zależny od płci: u dziewcząt rozpoczyna się wcześniej i trwa dłużej, ma wolniejszy i bardziej stabilny przebieg; u chłopców następuje później, jest zdecydowanie szybszy i bardziej burzliwy. Na początku tego okresu narastanie napięcia seksualnego i gotowość do jego zaspokojenia oraz do stworzenia bliskiej więzi z inną osobą są odrębnymi pragnieniami. Występuje dezintegracja seksualna okresu dorastania, czyli rozdźwięk między uczuciowością a podnieceniem i pożądaniem [11].

Okres dorastania jest związany $\mathrm{z}$ tendencją do eksperymentowania, poszukiwania nowych pól aktywności, chęcią sprawdzenia się. Łączy się to z wieloma zagrożeniami dla zdrowia i rozwoju młodzieży, zwłaszcza że młodzi ludzie czują się chronieni przed niebezpieczeństwem i nie myślą o konsekwencjach [12]. Zagrożenia okresu dorastania są immanentnie związane $\mathrm{z}$ tą fazą rozwoju człowieka. Zdobywanie nowych doświadczeń w tym okresie jest jednak warunkiem rozwoju. Dostrzega to między innymi E.H. Erikson, widząc w bogatej aktywności społecznej nastolatków szansę na to, aby w okresie dorosłości mogli wykorzystać zdolności rozwojowe [13].

W rozwoju psychoseksualnym występują duże różnice indywidualne. Zarówno w przypadku chłopców, jak i dziewcząt, wcześniejsze dojrzewanie seksualne współwystępuje z wcześniejszym rozpoczęciem współżycia seksualnego [14]. Zrozumienie prawidłowości rozwoju psychoseksualnego młodzieży wymaga także uwzględnienia opisanego przez Andrzeja Jaczewskiego zjawiska rozszczepienia dojrzewania. Na skutek jednoczesnego występowania akceleracji rozwoju fizycznego oraz przemian zachodzących we współczesnym społeczeństwie młodzież wcześniej osiąga dojrzałość biologiczną (na co wskazuje m.in. wiek pierwszej miesiączki), a znacznie później dojrzałość emocjonalną, moralną i społeczną, a także samodzielność ekonomiczną. Z tego powodu wczesna inicjacja seksualna podejmowana przez osobę, która nie uzyskała pełnej dojrzałości psychoseksualnej, może stanowić zagrożenie dla jej zdrowia seksualnego i reprodukcyjnego [15]. Wczesny wiek rozpoczęcia współżycia seksualnego zwiększa ryzyko podejmowania innych zachowań ryzykownych przez młodzież, takich jak: nieregularne stosowanie antykoncepcji, współżycie z wieloma partnerami seksualnymi, prostytucja, podejmowanie współżycia z osobami obcymi oraz częste zmiany partnerów seksualnych [16]. 
W prawidłowym przebiegu rozwoju psychoseksualnego dzieci i młodzieży w pierwszych latach życia dużą rolę odgrywa rodzina, w późniejszych znaczenia nabiera grupa rówieśnicza i inne agendy socjalizacji seksualnej. Rola rodziców w rozwoju młodzieży zaznacza się zarówno bezpośrednio, poprzez uwarunkowania biologiczne, jak i pośrednio poprzez zaspokojenie podstawowych potrzeb fizjologicznych, bezpieczeństwa, przynależności, uznania czy samorealizacji dzieci i młodzieży. Rodzice podejmują działania o charakterze opiekuńczym, socjalizacyjnym czy oddziałują na system poznawczy oraz moralny swoich dzieci. W ostatnich dwóch dekadach następują dynamiczne zmiany w roli poszczególnych agend socjalizacji seksualnej, a najważniejszą rolę w tym zakresie pełnią media elektroniczne, zwłaszcza Internet [17].

Młodzież w okresie dojrzewania doświadcza silnego i często odczuwanego napięcia seksualnego. Dotyczy to zwłaszcza chłopców. Normy religijne i społeczne nakazują nastolatkom odroczenie momentu podejmowania aktywności seksualnej, a nawet niepodejmowanie jej przed zawarciem małżeństwa. Niektórzy respektując te normy bądź kierując się innymi powodami, na przykład obawą przed ciążą, zachowują abstynencję seksualną. Jednak większość osób w tym wieku przeżywa młodzieńczą miłość, tworzy pierwsze związki, podejmuje jakąś formę aktywności seksualnej. Aktywność seksualna nastolatków może przybierać różne formy, wielu z nich podejmuje przedinicjacyjne formy aktywności seksualnej (pocałunki, netting, petting), masturbację, niektórzy mniej czy bardziej regularne współżycie seksualne [11]. Badania prowadzone w Polsce wskazują że bliskie kontakty seksualne bez współżycia wyprzedzają mniej więcej o rok inicjację seksualną [14]. Namiętne pocałunki, netting i petting są przedinicjacyjnymi formami partnerskiej aktywności seksualnej (chociaż niektóre osoby swoją aktywność seksualną rozpoczynają z ich pominięciem). Stanowią wstęp i przygotowanie do stosunków seksualnych. W badaniach zrealizowanych przez Z. Izdebskiego w 2004 roku wynika, że zdecydowana większość (83\%) osiemnastoletnich chłopców całowała się już kiedyś z kobietą/dziewczyną. Również większość dziewcząt w tym samym wieku (88\%) przyznała, że całowała się już kiedyś z mężczyzną/chłopakiem. Ponad połowa chłopców $(59 \%)$ i niemal co druga dziewczyna (48\%) przynajmniej raz była $w$ sytuacji, kiedy druga osoba namiętnie ją pieściła (to znaczy uprawiali petting) [14].

Inicjacja seksualna, czyli pierwszy stosunek płciowy, jest znaczącym wydarzeniem w życiu nastolatka, stanowi przejście do następnego etapu rozwoju psychoseksualnego, konstruuje jego heteroseksualność [18]. Wyniki badań Health Behaviour in School-aged Children (HBSC) wskazują, że częstość i wiek inicjacji seksualnej u nastolatków w różnych krajach są zróżnicowane. W większości krajów inicjacja seksualna jest wcześniejsza u chłopców niż u dziewcząt, ale różnice te stopniowo się zmniejszają. W krajach Europy Północnej inicjację seksualną częściej podejmują dziewczęta niż chłopcy; w latach 2002-2010 w rejonie Europy Wschodniej i Południowej częstość inicjacji seksualnej dziewcząt się zwiększała [19]. W Polsce obserwujemy ciagły wzrost odsetka młodzieży po inicjacji seksualnej. O ile w 1990 roku w badaniach HBSC stwierdzono, że w grupie osiemnastolatków 36\% chłopców i 18\% dziewcząt deklarowało odbycie inicjacji seksualnej [20], to w 2010 roku twierdziło już tak 45\% chłopców i 38\% dziewcząt [21], a w badaniach zrealizowanych przez Instytut Badań Edukacyjnych w 2015 roku, takie deklaracje uzyskano od 53\% chłopców oraz $48 \%$ dziewcząt [22]. Dane te obrazują także inną, zasygnalizowaną już tutaj, tendencję - znacząco szybszy wzrost odsetka osób po inicjacji seksualnej w grupie dziewcząt. Potwierdzają ją badania HBSC zrealizowane w roku 2014. Stwierdzono w nich, że inicjację seksualną odbyło 17,4\% ankietowanych 15-latków, nieznacznie częściej dziewczęta niż chłopcy (odpowiednio: 18,5\% vs $16,0 \%$ ) [23]. Tak więc pierwszy raz w historii badań zjawiska inicjacji seksualnej w Polsce proporcje pomiędzy chłopcami a dziewczętami się odwróciły.

Badania realizowane w Polsce pozwoliły na ustalenie listy czynników, które powoduja, że wzrasta prawdopodobieństwo podjęcia współżycia seksualnego przed uzyskaniem pełnoletności. W badaniach Z. Izdebskiego były to: palenie papierosów, picie piwa, częste upijanie się, spędzanie większości wieczorów w towarzystwie rówieśników, intensywne czy wyczynowe uprawianie sportu, deklarowanie się jako niewierzący (dla chłopców i dziewcząt), dobre warunki materialne, posiadanie dużej ilości pieniędzy na własne wydatki, mieszkanie w internacie i słabsze wyniki w nauce (dla chłopców), posiadanie rodziców preferujących styl kierowania równocześnie wymagający i ostry bądź niekonsekwentny lub nieinterweniujący, brak partnerskich stosunków między rodzicami, brak dobrej atmosfery w rodzinie i złe samopoczucie w domu rodzinnym, wagarowanie (dla dziewcząt) [24]. W badaniach HBSC do czynników ryzyka wczesnej inicjacji seksualnej zaliczono w przypadku dziewcząt: wagarowanie, palenie tytoniu, spędzanie wielu wieczorów z rówieśnikami, częste używanie amfetaminy i marihuany, łatwość rozmów z rówieśnikami płci przeciwnej oraz częste upijanie się, natomiast w przypadku chłopców: częste picie wódki i piwa, używanie amfetaminy, wagarowanie i uczęszczanie do zasadniczej szkoły zawodowej, niedostateczny monitoring za strony matki, częste upijanie się [25]. Analiza częstości inicjacji seksualnej w zależności od wybranych czynników socjodemograficznych, zrealizowana $w$ ramach badań HBSC $w$ roku 2014, wskazuje, że: częściej odbyła ją młodzież z rodzin zrekonstruowanych i niepełnych niż z rodzin z obojgiem biologicznych rodziców (różnice istotne statystycznie dotyczyły chłopców); występował związek inicjacji seksualnej z zamożnością rodziny (u dziewcząt ma on charakter nieliniowy); częściej podejmowały inicjację osoby $\mathrm{z}$ rodzin najbiedniejszych i najzamożniejszych (chłopcy z rodzin najbiedniejszych); częściej odbywali inicjację chłopcy i dziewczęta z małych miast [23].

Badania międzynarodowe $\mathrm{z}$ udziałem młodzieży $\mathrm{z}$ Polski oraz badania zrealizowane $\mathrm{w}$ innych krajach pozwalają na wykazanie znaczącej roli wielu cech rodziny jako czynników warunkujących inicjację seksualną. W badaniach HBSC młodzieży 15-letniej, zrealizowanych w pięciu państwach (Finlandia, Szkocja, Francja, 
Polska i USA), wykazano związek pomiędzy niskim statusem społeczno-ekonomicznym rodziny a wczesną inicjacją seksualną we wszystkich badanych krajach. Przy uwzględnieniu kryterium płci w Polsce wystąpiła bardzo silna zależność pomiędzy niskim statusem społeczno-ekonomicznym rodziny a inicjacją w grupie dziewcząt. Stwierdzono także, iż zależność pomiędzy komunikacją w rodzinie a wczesną inicjacją seksualną występuje tylko w USA, a nie występowała w czterech pozostałych krajach. Zwrócono uwagę na nieco inaczej brzmiące pytanie (w USA - satysfakcja z komunikacji, w innych krajach - łatwość w komunikacji), jednak nie można wykluczyć różnic kulturowych i etnicznych [26]. Zależność pomiędzy komunikacją w rodzinie a wczesną inicjacją seksualną wykazano także w innych badaniach zrealizowanych w USA, ale tylko w grupie dziewcząt [27]. W innych badaniach stwierdzono, że młode osoby wychowywane przez jednego rodzica lub pochodzące z rodzin o niskim statusie socjoekonomicznym (niski poziom wykształcenia rodziców, niskie aspiracje życiowe i zawodowe, niewysokie dochody), a także pochodzące $\mathrm{z}$ rodzin określających się jako niereligijne lub niewspierające rozpoczynają życie seksualne wcześniej niż ich rówieśnicy [28]. Osoby, których ojcowie byli wyżej wykształceni, później rozpoczynały współżycie seksualne. Taką samą zależność ustalono pomiędzy poziomem edukacji matek a inicjacją mężczyzn - im wyższe wykształcenie matki, tym późniejsze rozpoczęcie współżycia seksualnego przez syna [29]. Z wczesną inicjacją seksualną związane są takie cechy, jak niski status socjoekonomiczny oraz brak więzi i spójności w rodzinie [30]. Stwierdzono także istotny statystycznie związek między wiekiem inicjacji rodziców a wiekiem inicjacji seksualnej ich dzieci [31]. Przytoczone doniesienia badawcze, choć ciekawe poznawczo, nie zawsze mogą być odnoszone do rezultatów uzyskanych w innych badaniach, także prezentowanych w niniejszym opracowaniu, nie tylko ze względu na inny dobór próby czy operacjonalizację zmiennych, ale także na znaczące różnice kulturowe.

\section{Materiał i metoda}

Celem, który przyjęto w niniejszym opracowaniu, jest ukazanie związku między wybranymi czynnikami społeczno-demograficznymi i cechami rodzinnymi a pierwszymi (przedinicjacyjnymi) doświadczeniami seksualnymi i inicjacją seksualną podejmowaną przez młodzież. W opracowaniu wykorzystano wyniki badań ilościowych „Młodzież a zdrowie” przeprowadzonych w roku szkolnym 2014/2015 w ramach projektu badań statutowych BST 7/174100/2015.

Sformułowano następujące pytania badawcze:

- Jak często młodzież podejmuje przedinicjacyjne formy aktywności seksualnej oraz inicjację seksualną?

- Czy występują różnice w częstości podejmowania inicjacji seksualnej i posiadania pierwszych, przedinicjacyjnych doświadczeń seksualnych przez uczniów w zależności od płci, miejsca zamieszkania, typu szkoły oraz wybranych czynników rodzinnych?
- Jakie czynniki społeczno-demograficzne i rodzinne mają związek z pierwszymi doświadczeniami seksualnymi i inicjacją seksualną podejmowaną przez dziewczęta i chłopców?

W związku z tym przyjęto następującą operacjonalizację zmiennych:

\section{a) Zmienne zależne}

Pierwsze (przedinicjacyjne) doświadczenia seksualne zostały zdefiniowane jako doświadczenia poprzedzające współżycie płciowe, takie jak: namiętne pocałunki, pieszczoty miłosne. Młodzież miała odpowiedzieć na pytanie: $\mathrm{W}$ jakim wieku miałeś/aś pierwsze doświadczenia seksualne? Chodzi o doświadczenia poprzedzające współżycie płciowe (namiętne pocałunki, pieszczoty miłosne). Kategorie odpowiedzi: nie miałem/am takich doświadczeń; miałem/am, w wieku ... lat.

Inicjacja seksualna badana była przy użyciu dwóch pytań. W pierwszym pytano młodzież: Czy miałeś/aś już stosunek seksualny? Kategorie odpowiedzi: tak, nie. Drugie pytanie: Ile miałeś/aś lat, kiedy po raz pierwszy odbyłeś/aś stosunek płciowy? Kategorie odpowiedzi: 11 lat lub mniej, 12 lat, 13 lat, 14 lat, 15 lat, 16 lat, 17 lat, 18 lat lub więcej.

\section{b) Zmienne niezależne}

Cechy socjodemograficzne (płeć i miejsce zamieszkania, typ szkoły) oraz wybrane cechy rodziny (wykształcenie rodziców, zamożność rodziny, wsparcie rodziny i komunikacja w rodzinie). Zmienne dotyczące miejsca zamieszkania, subiektywnej oceny zamożności rodziny, wsparcia rodziny i komunikacji w rodzinie oraz przyjęte kategorie i utworzone na ich podstawie skale zostały zaczerpnięte z badań HBSC i są szczegółowo opisane $\mathrm{w}$ raporcie $\mathrm{z}$ tych badań [24]. Poniżej zostana omówione tylko skale wykorzystane $\mathrm{w}$ niniejszych analizach.

1. Sieć badawcza HBSC od lat posługuje się skalą zasobów materialnych rodziny FAS (Family Affluence Scale), która jest sukcesywnie modyfikowana. Wykorzystana $\mathrm{w}$ tych badaniach i analizach skala składa się z 6 pytań. Dotyczą one: posiadania własnego pokoju przez ucznia, liczby samochodów w rodzinie, liczby komputerów $\mathrm{w}$ rodzinie, wyjazdów z rodziną na wakacje lub ferie za granicę oraz liczby łazienek w domu i wyposażenia w zmywarkę do naczyń [32].

2. Skala komunikacji w rodzinie została zastosowana w polskim badaniu HBSC w 2009/2010 roku, a od 2013/2014 roku jest uwzględniona w międzynarodowym protokole tych badań. Jest to skrót skali Family Dynamics Measure II (FDM II), zawierający 4 stwierdzenia. Do każdego ze stwierdzeń dotyczących prawidłowej komunikacji (omawiania ważnych spraw, uważnego słuchania, wyjaśniania nieporozumień) badani mają się ustosunkować, wybierając jedną z 5 odpowiedzi, punktowanych od 0 do 4 . Pełen wynik skali uzyskiwany jest poprzez zsumowanie odpowiedzi na 4 itemy (zakres 0-16). 
3. Skala wsparcia ze strony rodziców jest zaadaptowanym do badań HBSC skrótem skali Multidimensional Scale of Perceived Social Support (MSPSS). Składa się z 4 stwierdzeń: moja rodzina bardzo stara się mi pomóc; moja rodzina daje mi potrzebną emocjonalną pomoc i wsparcie; mogę rozmawiać o moich problemach z rodziną; moja rodzina chętnie pomaga mi w podejmowaniu własnych decyzji. Za każdą odpowiedź można uzyskać od 0 do 6 punktów. Pełny wynik skali uzyskiwany jest poprzez obliczenie sumy uzyskanych punktów (zakres 0-24).

Narzędziem badawczym był kwestionariusz ankiety, który został opracowany na potrzeby badań. Kwestionariusz zawierał pytania wchodzące w skład kwestionariusza używanego w badaniach HBSC w edycji badań w 2014 roku [24] oraz pytań dodatkowo opracowanych przez zespół badawczy. W analizie statystycznej zastosowano wielomianową regresję logistyczną, w której dopuszcza się, aby zmienna zależna przyjmowała więcej niż dwie wartości. Przyjęto za grupę odniesienia młodzież, która nie ma jeszcze za sobą żadnych doświadczeń seksualnych, badając osobno czynniki warunkujące posiadanie doświadczeń przedinicjacyjnych i podejmowanie inicjacji seksualnej. Wyniki przedstawiono jako wskaźniki ilorazu szans (OR - odds ratio) wraz z 95-procentowym przedziałem ufności. Oszacowano odrębne modele dla chłopców i dziewcząt. Obliczenia wykonano w pakiecie statystycznym PS Imago (IBM SPSS Statistics).

Badania ankietowe były przeprowadzane na terenie 4 województw (mazowieckiego, lubuskiego, podkarpackiego i pomorskiego) w 71 szkołach ponadgimnazjalnych metodą audytoryjną, wśród uczniów klas drugich i trzecich szkół ponadgimnazjalnych. Za organizację i realizację badania odpowiedzialny był przeszkolony ankieter.

Zbadano 1348 uczniów (733 chłopców i 615 dziewcząt). Po kontroli logicznej odpowiedzi oraz uwzględnieniu kryterium wieku do próby będącej podstawą prezentowanych analiz zaklasyfikowano 1266 uczniów, w tym 688 chłopców i 578 dziewcząt. Charakterystykę społeczno-demograficzną próby badawczej zamieszczono w Tabeli I. Średni wiek respondentów wynosił 17,86 $\pm 0,41$ roku. $\mathrm{W}$ badanej grupie $54,5 \%$ osób mieszkało w dużych i mniejszych miastach, a 45,4\% na wsi. Miejsce zamieszkania było czynnikiem różnicującym grupę dziewcząt i chłopców. Dziewczęta częściej niż chłopcy były mieszkankami miast (odpowiednio: 59\% i 51\%), różnice były istotne statystycznie. Ponad połowa badanej młodzieży $(53,7 \%)$ uczyła się w liceum ogólnokształcącym, co trzeci respondent uczęszczał do technikum $(33,2 \%)$, a co dziesiąty $(13,1 \%)$ do zasadniczej szkoły zawodowej. Dziewczęta częściej niż chłopcy uczęszczały do liceum ogólnokształcącego (odpowiednio: 72,8\% i 37,6\%), chłopcy częściej byli uczniami techników i za-

\begin{tabular}{|c|c|c|c|c|}
\hline & $\begin{array}{c}\text { Ogółem } \\
\mathrm{N}=1266\end{array}$ & $\begin{array}{l}\text { Chlopcy } \\
\text { N }=688\end{array}$ & $\begin{array}{c}\text { Dziewczęta } \\
\mathbf{N}=\mathbf{5 7 8}\end{array}$ & $\mathbf{p}$ \\
\hline $\begin{array}{l}\text { Miejsce zamieszkania: } \\
\text { - duże miasta } \\
\text { - małe miasta } \\
\text { - } \text { rejony wiejskie }\end{array}$ & $\begin{array}{l}34,1 \\
20,5 \\
45,4\end{array}$ & $\begin{array}{l}32,1 \\
18,9 \\
49,0\end{array}$ & $\begin{array}{l}36,5 \\
22,5 \\
41,0\end{array}$ & 0,017 \\
\hline $\begin{array}{l}\text { Typ szkoły: } \\
\text { - liceum ogólnokształcące } \\
\text { - technikum } \\
\text { - zasadnicza szkoła zawodowa }\end{array}$ & $\begin{array}{l}53,7 \\
33,2 \\
13,1\end{array}$ & $\begin{array}{l}37,6 \\
44,9 \\
17,5\end{array}$ & $\begin{array}{r}72,8 \\
19,2 \\
8,0\end{array}$ & $<0,001$ \\
\hline $\begin{array}{l}\text { Wykształcenie matki: } \\
\text { - } \quad \text { poniżej średniego } \\
\text { - } \quad \text { średnie lub zaczęte studia } \\
\text { - } \quad \text { wyższe (w tym licencjackie) }\end{array}$ & $\begin{array}{r}6,0 \\
61,0 \\
33,0\end{array}$ & $\begin{array}{r}5,7 \\
62,4 \\
31,9\end{array}$ & $\begin{array}{r}6,3 \\
59,4 \\
34,3\end{array}$ & 0,585 \\
\hline $\begin{array}{l}\text { Wykształcenie ojca: } \\
\text { - } \quad \text { poniżej średniego } \\
\text { - } \quad \text { średnie lub zaczęte studia } \\
\text { - } \quad \text { wyższe (w tym licencjackie) }\end{array}$ & $\begin{array}{r}8,8 \\
66,8 \\
24,4\end{array}$ & $\begin{array}{r}8,6 \\
68,5 \\
33,9\end{array}$ & $\begin{array}{r}9,1 \\
64,7 \\
26,2\end{array}$ & 0,405 \\
\hline $\begin{array}{l}\text { Zamożność rodziny: } \\
\text { - biedna } \\
\text { - przeciętna } \\
\text { - zamożna }\end{array}$ & $\begin{array}{l}24,7 \\
46,6 \\
28,7\end{array}$ & $\begin{array}{l}23,9 \\
47,1 \\
29,0\end{array}$ & $\begin{array}{l}25,7 \\
46,0 \\
28,3\end{array}$ & 0,770 \\
\hline Wiek (średnia \pm SD) & $17,86 \pm 0,41$ & $17,88 \pm 0,42$ & $17,82 \pm 0,40$ & 0,009 \\
\hline
\end{tabular}

Tabela I. Charakterystyka próby pod względem cech społeczno-demograficznych, dane w\%. Źródto: Opracowanie własne. 
sadniczych szkół zawodowych. W badanej grupie ponad $3 / 5$ respondentów posiadało matkę lub ojca $\mathrm{z}$ wykształceniem średnim $(61,0 \% ; 66,8 \%)$, rzadziej z wyższym $(33,0 \% ; 24,4 \%)$ i poniżej średniego $(6,0 \% ; 8,8 \%)$. Większość badanej młodzieży pochodziła z rodzin, których zasoby materialne były na poziomie przeciętnym $(46,6 \%)$, rzadziej z rodzin zamożnych $(28,7 \%)$ i mających niski status materialny $(24,7 \%)$.

Średni indeks wsparcia w rodzinie wśród badanej młodzieży wynosił 16,93 \pm 5,9 i nie wykazał istotnych różnic statystycznych związanych z płcią badanych osób. Po uwzględnieniu podziału skali wsparcia w rodzinie na trzy kategorie (niskie, przeciętne, wysokie) prawie $3 / 5$ młodzieży znalazło się w grupie o przeciętnym wsparciu $(61,4 \%)$, a pozostałe osoby w grupach o niskim $(20,6 \%)$ i wysokim wsparciu (18\%).

Wśród badanych średni indeks komunikacji w rodzinie wynosił $11,02 \% \pm 3,23$. Po podziale na trzy kategorie komunikacja w większości rodzin osób badanych była przeciętna $(58,7 \%)$, w co piątej rodzinie słaba $(19,6 \%)$ lub dobra (21,7\%). Wykazano, że płeć jest tu czynnikiem istotnie różnicującym, chociaż różnice są bardziej widoczne w odniesieniu do wartości średniej niż po podziale na kategorie (Tabela II).

Zestawienie rodzaju szkoły, do której uczęszczali badani, z pozytywnymi wskaźnikami dotyczącymi rodziny, takimi jak: dobra komunikacja, wysokie wsparcie, wysoki status materialny, wyższe wykształcenie matki i ojca, wykazało, że częściej dotyczą one młodzieży uczącej się w liceum ogólnokształcącym. W przypadku wyższego wykształcenia rodziców i wysokiej zamożności rodziny można zauważyć, że rzadziej występowały u uczniów technikum niż liceów ogólnokształcących, ale częściej niż u uczniów zasadniczych szkół zawodowych. W przypadku wysokiego wsparcia w rodzinie i dobrej komunikacji w rodzinie można mówić o ich równie częstym występowaniu u osób uczęszczających do techników i zasadniczych szkół zawodowych (Wykres 1).

\begin{tabular}{|c|c|c|c|c|}
\hline Relacje rodzinne & $\begin{array}{c}\text { Ogólem } \\
\mathrm{N}=1266\end{array}$ & $\begin{array}{l}\text { Chlopcy } \\
N=688 \\
\end{array}$ & $\begin{array}{c}\text { Dziewczęta } \\
\mathbf{N}=\mathbf{5 7 8}\end{array}$ & $\mathbf{p}$ \\
\hline \multicolumn{5}{|l|}{ Wsparcie w rodzinie: } \\
\hline - niskie & 20,6 & 19,0 & 22,5 & \multirow{3}{*}{0,302} \\
\hline - przeciętne & 61,4 & 63,0 & 59,5 & \\
\hline - wysokie & 18,0 & 18,0 & 18,1 & \\
\hline Średni indeks wsparcia & $16,93 \pm 5,90$ & $17,04 \pm 5,80$ & $16,79 \pm 6,01$ & 0,451 \\
\hline \multicolumn{5}{|l|}{ Komunikacja w rodzinie: } \\
\hline - słaba & 19,6 & 18,5 & 20,9 & \multirow{3}{*}{0,538} \\
\hline - przeciętna & 58,7 & 59,8 & 57,5 & \\
\hline - dobra & 21,7 & 21,7 & 21,6 & \\
\hline Średni indeks komunikacji & $11,02 \pm 3,23$ & $11,19 \pm 3,12$ & $10,81 \pm 3,36$ & 0,041 \\
\hline
\end{tabular}

Tabela II. Charakterystyka próby pod względem relacji rodzinnych, dane $w \%$. Źródto: Opracowanie własne.

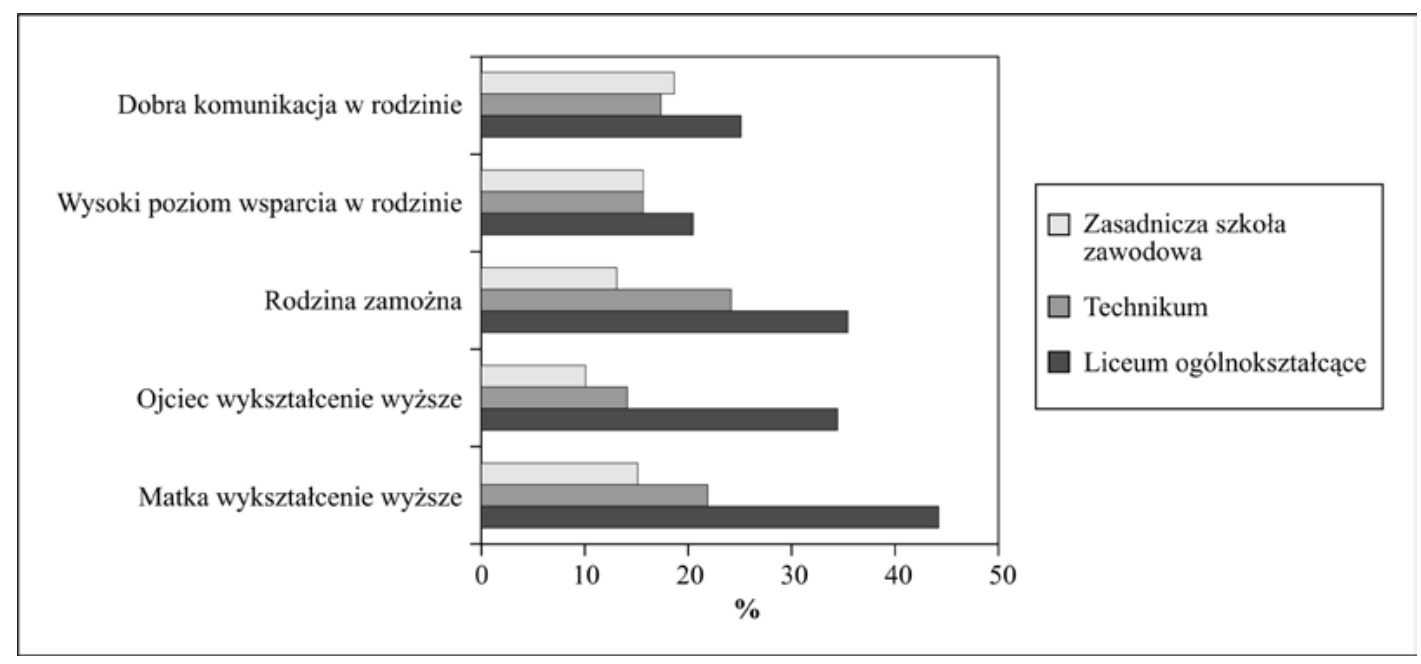

Wykres 1. Wybrane charakterystyki rodzin uczniów 18-letnich wedlug typu szkoły. Źródto: Opracowanie własne. 


\section{Wyniki}

Zestawienie wybranych cech społeczno-demograficznych osób badanych (płci, typu szkoły i miejsca zamieszkania) oraz wybranych cech ich rodzin (wykształcenia rodziców, zamożności rodziny, wsparcia rodziny i komunikacji w rodzinie) z posiadaniem przez nich przedinicjacyjnych doświadczeń seksualnych i podjęciem inicjacji seksualnej pozwoliło zrealizować przyjęty cel badań, podjać próbę odpowiedzi na pytania badawcze.

Wśród badanej młodzieży $64,5 \%$ osób miało za sobą doświadczenia seksualne, w tym $24,6 \%$ posiadało doświadczenia poprzedzające stosunek seksualny, takie jak namiętne pocałunki, pieszczoty miłosne, a 39,9\% odbyło stosunek seksualny. Analiza posiadania doświadczeń seksualnych z uwzględnieniem płci badanej młodzieży wykazała, że częściej aktywność seksualną podejmowali chłopcy niż dziewczęta $\left(\chi^{2}=10,75 \mathrm{df}-2 ; \mathrm{p}=0,005\right)$.

Osoby, które mają za sobą inicjację seksualną, wcześniej podejmowały inne formy aktywności seksualnej od osób, które poprzestały na przedinicjacyjnych doświadczeniach seksualnych, przy tym wiek, w którym była podejmowana przedinicjacyjna aktywność seksualna, różnicuje płeć osób badanych. Co prawda w przypadku osób, które mają za sobą tylko doświadczenia przedinicjacyjne, średni wiek ich uzyskania u chłopców i dziewcząt jest podobny (odpowiednio: 15,38; 15,55), jednak średni wiek uzyskania takich doświadczeń przez chłopców i dziewczęta, które następnie odbyły inicjację seksualną, różni się znacząco (odpowiednio: 14,18; 15,02).
Jest to także silnie zróżnicowane u poszczególnych osób, zarówno w przypadku chłopców, jak i dziewcząt (odchylenie standardowe, odpowiednio: 3,$89 ; 2,83$ ).

Zestawienie posiadania doświadczeń seksualnych z typem szkoły i miejscem zamieszkania z uwzględnieniem kryterium płci wykazało, że występują istotne różnice statystyczne tylko w przypadku typu szkoły. Wśród chłopców uczących się w LO było więcej osób, które miały za sobą pierwsze doświadczenia seksualne, niż w technikach i zasadniczych szkołach zawodowych (odpowiednio: 29,4\%, 21,3\% i 13,9\%). W przypadku odbycia stosunku seksualnego zależność ta ma odwrotny kierunek. W LO było najmniej uczniów po inicjacji seksualnej (36,5\%), a w ZSZ najwięcej (62,6\%). Różnice statystyczne nie występowały w przypadku włączenia do analiz miejsca zamieszkania, choć dziewczęta zamieszkałe w dużych miastach częściej miały stosunek seksualny niż ich koleżanki mieszkające w mniejszych miastach i na wsi (Tabela III).

Analiza związków doświadczeń seksualnych chłopców z wybranymi cechami rodziny, takimi, jak: wykształcenie rodziców, zasoby materialne rodziny, komunikacja $\mathrm{w}$ rodzinie, wsparcie $\mathrm{w}$ rodzinie, wykazała, że tylko zasoby materialne rodziny i wsparcie rodzinne w sposób istotny statystycznie różnicują podejmowanie aktywności seksualnej przez badanych. Chłopcy pochodzący z rodzin o niskim statusie materialnym częściej nie posiadaja żadnych doświadczeń seksualnych niż ich koledzy $\mathrm{z}$ rodzin o przeciętnym i wysokim poziomie ekonomicznym (odpowiednio: 43,6\%, 31,0\%, 26,7\%).

\begin{tabular}{|c|c|c|c|c|}
\hline \multirow[b]{2}{*}{ Cechy rodziny } & \multicolumn{3}{|c|}{ Rodzaj dotychczasowych doświadczeń } & \multirow[b]{2}{*}{$\mathbf{p}$} \\
\hline & Brak & $\begin{array}{l}\text { Doświadczenia } \\
\text { przedinicjacyjne }\end{array}$ & $\begin{array}{c}\text { Inicjacja } \\
\text { seksualna }\end{array}$ & \\
\hline Chlopcy & 32,6 & 23,4 & 44,0 & \\
\hline $\begin{array}{l}\text { Miejsce zamieszkania: } \\
\text { - duże miasta } \\
\text { - małe miasta } \\
\text { - } \text { rejony wiejskie }\end{array}$ & $\begin{array}{l}34,0 \\
32,2 \\
31,4\end{array}$ & $\begin{array}{l}24,1 \\
24,0 \\
23,1\end{array}$ & $\begin{array}{l}42,0 \\
43,8 \\
45,5\end{array}$ & 0,952 \\
\hline $\begin{array}{l}\text { Typ szkoły: } \\
\text { - liceum ogólnokształcące } \\
\text { - } \text { technikum } \\
\text { - } \text { zasadnicza szkoła zawodowa }\end{array}$ & $\begin{array}{l}34,1 \\
34,8 \\
23,5\end{array}$ & $\begin{array}{l}29,4 \\
21,8 \\
13,9\end{array}$ & $\begin{array}{l}36,5 \\
43,3 \\
62,6\end{array}$ & $<0,001$ \\
\hline Dziewczęta & 39,0 & 26,0 & 34,9 & \\
\hline $\begin{array}{l}\text { Miejsce zamieszkania: } \\
\text { - duże miasta } \\
\text { - małe miasta } \\
\text { - } \text { rejony wiejskie }\end{array}$ & $\begin{array}{l}34,0 \\
42,4 \\
42,0\end{array}$ & $\begin{array}{l}24,5 \\
23,2 \\
29,0\end{array}$ & $\begin{array}{l}41,5 \\
34,4 \\
29,0\end{array}$ & 0,080 \\
\hline $\begin{array}{l}\text { Typ szkoły: } \\
\text { - liceum ogólnokształcące } \\
\text { - } \text { technikum } \\
\text { - } \text { zasadnicza szkoła zawodowa }\end{array}$ & $\begin{array}{l}41,6 \\
27,4 \\
43,2\end{array}$ & $\begin{array}{r}31,1 \\
13,2 \\
9,1\end{array}$ & $\begin{array}{l}27,3 \\
59,4 \\
47,7\end{array}$ & $<0,001$ \\
\hline
\end{tabular}

Tabela III. Doświadczenia seksualne w zależności od ptci, typu szkoły i miejsca zamieszkania, dane w\%. Źródto: Opracowanie własne. 
Chłopcy pochodzący z rodzin o niskim statusie materialnym rzadziej niż ich rówieśnicy z rodzin o przeciętnym i wysokim statusie ekonomicznym mają za sobą przedinicjacyjne doświadczenia seksualne (odpowiednio: 16,0, $27,8,23,0$ ), natomiast chłopcy z rodzin o wysokim statusie ekonomicznym wyraźnie częściej niż ich koledzy z rodzin o przeciętnym i niskim poziomie materialnym podejmowali inicjację seksualną (odpowiednio: 50,3, 41,2, 40,4).

Chłopcy pochodzący z rodzin o niskim wsparciu częściej mieli już za sobą stosunek seksualny $(56,7 \%)$ niż ich rówieśnicy, których rodzinom przypisano przeciętny i wysoki poziom wsparcia (odpowiednio: 40,5\% i 42,0\%) (Tabela IV).

Analiza związków doświadczeń seksualnych dziewcząt z wykształceniem rodziców, zasobami materialnymi rodziny, komunikacją w rodzinie i wsparciem w rodzinie wykazały, że jedynie zasoby materialne rodziny istotnie statystycznie różnicowały ich zachowania. W przeciwieństwie do grupy chłopców pierwsze, przedinicjacyjne doświadczenia seksualne częściej miały za sobą dziewczęta, które pochodziły z rodzin o wysokim i przeciętnym statusie materialnym (odpowiednio: 29,9\%, 28,2\%) niż ich rówieśniczki pochodzące $\mathrm{z}$ rodzin o niskich zasobach materialnych $(17,1 \%)$. W przypadku inicjacji seksualnej proporcje były odwrócone - częściej inicjację seksualną miały już za sobą dziewczęta pochodzące z rodzin o niskim statusie materialnym niż wywodzące się $\mathrm{z}$ rodzin o przeciętnym i wysokim statusie materialnym (odpowiednio: 41,4\%, 35,7\%, 28,0\%) (Tabela V).

$\mathrm{W}$ analizach społeczno-demograficznych i rodzinnych uwarunkowań podejmowania inicjacji seksualnej i posiadania pierwszych doświadczeń seksualnych wykorzystano modele regresji logistycznej wielomianowej. W opracowanym modelu za grupę odniesienia dla zmiennych zależnych (inicjacja seksualna, wczesne doświadczenia seksualne) przyjęto młodzież niemającą doświadczeń seksualnych. Dla grup zmiennych niezależnych za kategorię referencyjną dla zamożności rodziny przyjęto rodziny zamożne oraz uczniów z zasadniczych szkół zawodowych. Analizy korygowano również ze względu na wykształcenie ojca i matki, miejsce zamieszkania i komunikację w rodzinie.

Wyniki estymacji modelu regresji logistycznej pozwoliły wykazać, że w populacji chłopców w porównaniu z rówieśnikami, którzy nie mają za sobą żadnych doświadczeń seksualnych, czynnikiem ryzyka inicjacji seksualnej jest niskie wsparcie rodziny oraz wysoki poziom zamożności, natomiast czynnikiem chroniącym przed inicjacją - uczęszczanie do liceum ogólnokształcącego lub technikum. Jeżeli porównamy chłopców niemających $\mathrm{w}$ ogóle doświadczeń seksualnych $\mathrm{z}$ rówieśnikami, którzy mieli pierwsze doświadczenia, ale bez stosunku płciowego, to potwierdza się jedynie związek z zamożnością rodziny. Aktywność seksualną rzadziej podejmują chłopcy z uboższych rodzin (Tabela VI).

\begin{tabular}{|c|c|c|c|c|}
\hline \multirow[b]{2}{*}{ Cechy rodziny } & \multicolumn{3}{|c|}{ Rodzaj dotychczasowych doświadczeń } & \multirow[b]{2}{*}{$\mathbf{p}$} \\
\hline & Brak & $\begin{array}{c}\text { Doświadczenia } \\
\text { przedinicjacyjne }\end{array}$ & Inicjacja seksualna & \\
\hline $\begin{array}{l}\text { Wykształcenie matki: } \\
\text { - } \quad \text { poniżej średniego } \\
\text { - } \quad \text { średnie lub zaczęte studia } \\
\text { - } \quad \text { wyższe (w tym licencjackie) }\end{array}$ & $\begin{array}{l}33,3 \\
32,3 \\
29,6\end{array}$ & $\begin{array}{r}9,1 \\
22,5 \\
26,5\end{array}$ & $\begin{array}{l}57,6 \\
45,2 \\
43,9\end{array}$ & 0,258 \\
\hline $\begin{array}{l}\text { Wykształcenie ojca: } \\
\text { - } \text { poniżej średniego } \\
\text { - } \quad \text { średnie lub zaczęte studia } \\
\text { - } \quad \text { wyższe (w tym licencjackie) }\end{array}$ & $\begin{array}{l}36,0 \\
30,1 \\
32,6\end{array}$ & $\begin{array}{l}16,0 \\
23,7 \\
25,8\end{array}$ & $\begin{array}{l}48,0 \\
46,3 \\
41,7\end{array}$ & 0,620 \\
\hline $\begin{array}{l}\text { Zamożność rodziny: } \\
\text { - biedna } \\
\text { - przeciętna } \\
\text { - zamożna }\end{array}$ & $\begin{array}{l}43,6 \\
31,0 \\
26,7\end{array}$ & $\begin{array}{l}16,0 \\
27,8 \\
23,0\end{array}$ & $\begin{array}{l}40,4 \\
41,2 \\
50,3\end{array}$ & 0,002 \\
\hline $\begin{array}{l}\text { Wsparcie w rodzinie: } \\
\text { - niskie } \\
\text { - przeciętne } \\
\text { - wysokie }\end{array}$ & $\begin{array}{l}22,5 \\
34,5 \\
35,3\end{array}$ & $\begin{array}{l}20,8 \\
25,0 \\
22,7\end{array}$ & $\begin{array}{l}56,7 \\
40,5 \\
42,0\end{array}$ & 0,028 \\
\hline $\begin{array}{l}\text { Komunikacja w rodzinie: } \\
\text { - słaba } \\
\text { - przeciętna } \\
\text { - dobra }\end{array}$ & $\begin{array}{l}26,1 \\
34,5 \\
31,7\end{array}$ & $\begin{array}{l}24,4 \\
24,0 \\
21,8\end{array}$ & $\begin{array}{l}49,6 \\
41,4 \\
46,5\end{array}$ & 0,416 \\
\hline
\end{tabular}

Tabela IV. Doświadczenia seksualne chłopców w zależności od cech rodziny, dane w\%. Źródto: Opracowanie własne. 


\begin{tabular}{|c|c|c|c|c|}
\hline \multirow[b]{2}{*}{ Cechy rodziny } & \multicolumn{3}{|c|}{ Rodzaj dotychczasowych doświadczeń } & \multirow[b]{2}{*}{$\mathbf{p}$} \\
\hline & Brak & $\begin{array}{c}\text { Doświadczenia } \\
\text { przedinicjacyjne }\end{array}$ & Inicjacja seksualna & \\
\hline $\begin{array}{l}\text { Wykształcenie matki: } \\
\text { - } \quad \text { poniżej średniego } \\
\text { - } \quad \text { średnie lub zaczęte studia } \\
\text { - } \quad \text { wyższe (w tym licencjackie) }\end{array}$ & $\begin{array}{l}31,3 \\
39,4 \\
41,0\end{array}$ & $\begin{array}{l}25,0 \\
28,4 \\
23,6\end{array}$ & $\begin{array}{l}43,2 \\
36,1 \\
29,9\end{array}$ & 0,690 \\
\hline $\begin{array}{l}\text { Wykształcenie ojca: } \\
\text { - } \quad \text { poniżej średniego } \\
\text { - } \quad \text { średnie lub zaczęte studia } \\
\text { - } \quad \text { wyższe (w tym licencjackie) }\end{array}$ & $\begin{array}{l}36,4 \\
35,5 \\
46,5\end{array}$ & $\begin{array}{l}20,5 \\
28,4 \\
23,6\end{array}$ & $\begin{array}{l}43,2 \\
36,1 \\
29,9\end{array}$ & 0,186 \\
\hline $\begin{array}{l}\text { Zamożność rodziny: } \\
\text { - biedna } \\
\text { - przeciętna } \\
\text { - zamożna }\end{array}$ & $\begin{array}{l}41,4 \\
36,1 \\
42,0\end{array}$ & $\begin{array}{l}17,1 \\
28,2 \\
29,9\end{array}$ & $\begin{array}{l}41,4 \\
35,7 \\
28,0\end{array}$ & 0,030 \\
\hline $\begin{array}{l}\text { Wsparcie w rodzinie: } \\
\text { - niskie } \\
\text { - przeciętne } \\
\text { - wysokie }\end{array}$ & $\begin{array}{l}31,5 \\
39,6 \\
45,5\end{array}$ & $\begin{array}{l}24,2 \\
28,4 \\
20,2\end{array}$ & $\begin{array}{l}44,4 \\
32,0 \\
34,3,\end{array}$ & 0,061 \\
\hline $\begin{array}{l}\text { Komunikacja w rodzinie: } \\
\text { - słaba } \\
\text { - przeciętna } \\
\text { - dobra }\end{array}$ & $\begin{array}{l}36,8 \\
37,5 \\
45,4\end{array}$ & $\begin{array}{l}27,2 \\
27,8 \\
20,2\end{array}$ & $\begin{array}{l}36,0 \\
34,7 \\
34,5\end{array}$ & 0,459 \\
\hline
\end{tabular}

Tabela V. Doświadczenia seksualne dziewcząt $w$ zależności od cech rodziny, dane $w \%$.

Źródło: Opracowanie własne.

\begin{tabular}{|c|c|c|c|c|c|c|c|}
\hline \multirow{2}{*}{$\begin{array}{l}\text { Poziom zmiennej } \\
\text { zależnej }\end{array}$} & \multirow{2}{*}{ Zmienna niezależna } & \multirow{2}{*}{ B } & \multirow{2}{*}{$\begin{array}{c}\text { Bląd } \\
\text { standardowy }\end{array}$} & \multirow{2}{*}{$\mathbf{p}$} & \multirow{2}{*}{ OR } & \multicolumn{2}{|c|}{$\begin{array}{l}\text { 95\% przedzial ufności dla } \\
\text { OR }\end{array}$} \\
\hline & & & & & & $\begin{array}{c}\text { Dolna } \\
\text { granica }\end{array}$ & $\begin{array}{c}\text { Górna } \\
\text { granica }\end{array}$ \\
\hline Inicjacja seksualna & $\begin{array}{l}\text { Stała } \\
\text { Typ szkoły: } \\
\text { - liceum } \\
\text { - technikum } \\
\text { Zamożność rodziny: } \\
\text { - uboga } \\
\text { - przeciętna } \\
\text { Wsparcie rodziny: } \\
\text { - niskie } \\
\text { - przeciętne }\end{array}$ & $\begin{array}{r}1,669 \\
-1,562 \\
-1,018 \\
-1,348 \\
-0,617 \\
0,955 \\
0,199\end{array}$ & $\begin{array}{l}0,324 \\
0,265 \\
0,419 \\
0,313\end{array}$ & $\begin{array}{l}0,000 \\
0,000 \\
0,003 \\
\\
0,000 \\
0,020 \\
0,023 \\
0,524\end{array}$ & $\begin{array}{l}0,210 \\
0,361 \\
0,260 \\
0,540 \\
\\
2,599 \\
1,221\end{array}$ & $\begin{array}{l}0,103 \\
0,185 \\
0,138 \\
0,321 \\
1,143 \\
0,661\end{array}$ & $\begin{array}{l}0,427 \\
0,707 \\
0,490 \\
0,907 \\
\\
5,909 \\
2,255\end{array}$ \\
\hline $\begin{array}{l}\text { Przedinicjacyjne } \\
\text { doświadczenia } \\
\text { seksualne }\end{array}$ & $\begin{array}{l}\text { Stała } \\
\text { Zamożność rodziny: } \\
\text { - uboga } \\
\text { - przeciętna }\end{array}$ & $\begin{array}{l}-0,062 \\
-1,056 \\
-0,245\end{array}$ & $\begin{array}{l}0,575 \\
0,379 \\
0,298\end{array}$ & $\begin{array}{l}0,914 \\
0,005 \\
0,411\end{array}$ & $\begin{array}{l}0,348 \\
0,783\end{array}$ & $\begin{array}{l}0,165 \\
0,437\end{array}$ & $\begin{array}{l}0,732 \\
1,403\end{array}$ \\
\hline
\end{tabular}

* Grupę odniesienia stanowi młodzież niemajaca doświadczeń seksualnych; kategoriq referencyjnq sq rodziny zamożne oraz uczniowie zasadniczych szkót zawodowych; analizy korygowano ze względu na wykształcenie ojca i matki, miejsce zamieszkania $i$ komunikacje w rodzinie; OR - odds ratio.

Tabela VI. Wyniki estymacji modelu regresji logistycznej wielomianowej dla chtopców.

Źródto: Opracowanie własne. 


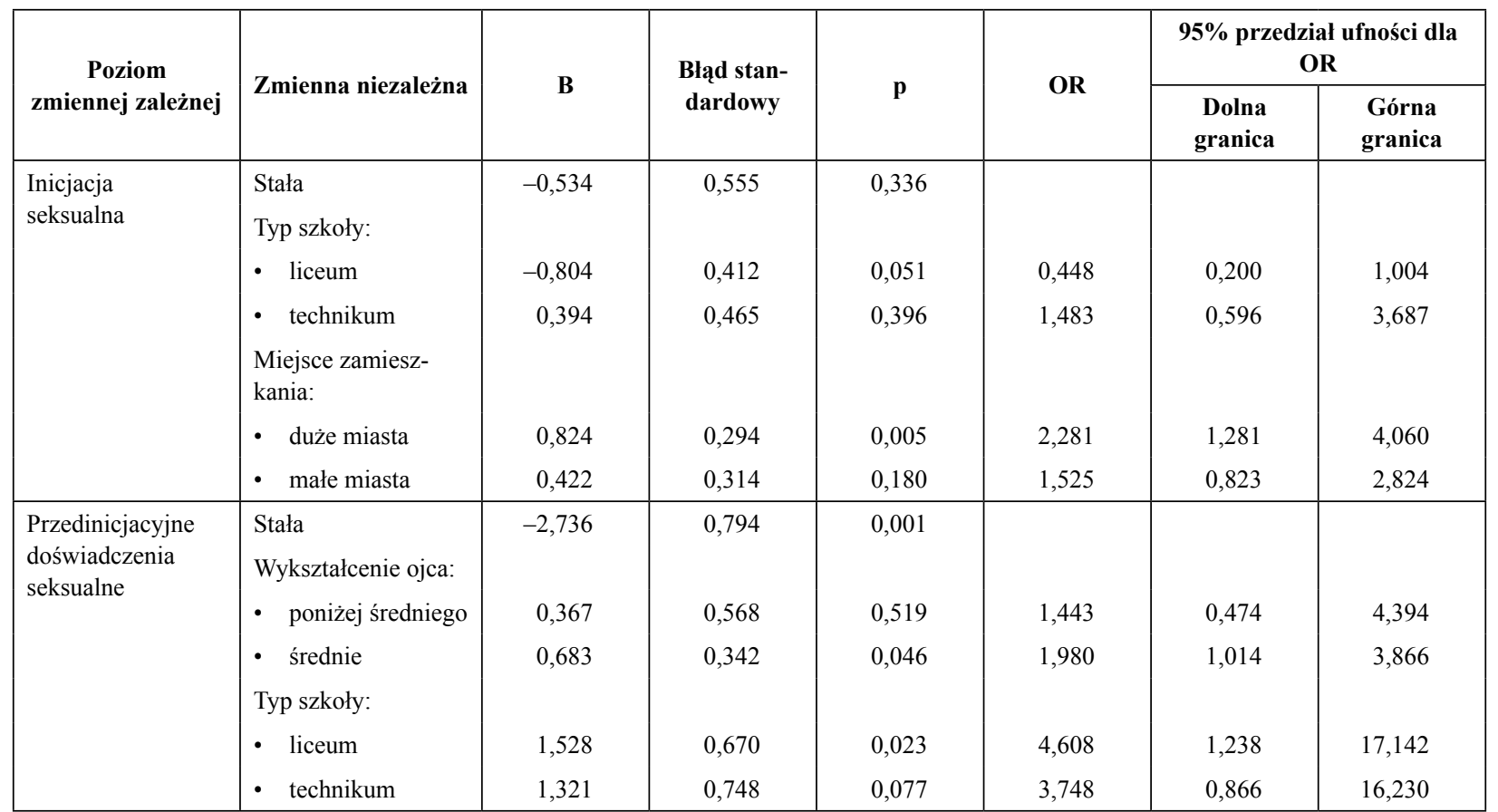

* Grupę odniesienia stanowi młodzież niemajaca doświadczeń seksualnych; kategoriq referencyjnq sq uczennice zasadniczych szkót zawodowych, mieszkanki rejonów wiejskich oraz córki ojców z wyksztatceniem powyżej średniego; analizy korygowano ze względu na wykształcenie matki, zamożność rodziny oraz wsparcie i komunikacje w rodzinie; OR - odds ratio.

Tabela VII. Wyniki estymacji modelu regresji logistycznej wielomianowej dla dziewczqt.

Źródto: Opracowanie własne.

Wyniki analogicznych analiz $\mathrm{w}$ grupie dziewcząt wykazały, że czynnikiem chroniącym przed inicjacją seksualną jest uczęszczanie do liceum ogólnokształcącego, natomiast czynnikiem ryzyka - zamieszkiwanie w dużym mieście. Jeżeli porównamy dziewczęta niemające $\mathrm{w}$ ogóle doświadczeń seksualnych z rówieśniczkami, które miały przedinicjacyjne doświadczenia seksualne, to zarysowuje się związek z wykształceniem ojca i z typem szkoły. Cześciej pierwsze doświadczenia seksualne miały córki ojców z wykształceniem średnim niż ich rówieśniczki posiadające ojca legitymującego się wykształceniem wyższym. Związek z typem szkoły przyjmuje odwrotny kierunek niż w przypadku inicjacji seksualnej - uczęszczanie do liceum ogólnokształcącego jest czynnikiem ryzyka. W modelu wielowymiarowym brak jest związku między zamożnością rodziny i wsparciem rodziny a posiadaniem doświadczeń seksualnych (Tabela VII).

\section{Podsumowanie i wnioski}

Z przeprowadzonych analiz wynika, że ponad 3/5 badanej młodzieży uczącej się w szkołach ponadgimnazjalnych $\mathrm{w}$ wieku 18 lat miało za sobą doświadczenia seksualne, $\mathrm{z}$ tego $2 / 5$ odbyło już stosunek seksualny. Po uwzględnieniu kryterium płci wykazano, że dziewczęta rzadziej niż chłopcy miały za sobą inicjację seksualną, ale częściej niż oni podejmowały przedinicjacyjne formy aktywności seksualnej. Badania potwierdziły znaczącą skalę aktywności seksualnej młodzieży i duże zróżnico- wanie w tym zakresie. Zapewne można to uznać za efekt różnych postaw wobec podejmowania aktywności seksualnej prezentowanych przez adolescentów, co opisuje w swoich pracach Irena Obuchowska [33]. W przypadku danych dotyczących inicjacji seksualnej należy przy tym wziąć pod uwagę obserwowaną współcześnie tendencję do podejmowania przez nastolatków stosunków oralnych i analnych, o czym świadczą wyniki badań zrealizowanych w 2011 roku przez Z. Izdebskiego [14]. Zjawisko to sprawia, że w badaniach należałoby uwzględniać róże formy aktywności seksualnej, które mogą i powinny być traktowane jako inicjacja seksualna.

Osoby, które mają za sobą inicjację seksualną wcześniej od osób, które jeszcze jej nie odbyły, podejmowały inne formy aktywności seksualnej. Wiek, w którym była podejmowana przedinicjacyjna aktywność seksualna, różnicuje płeć osób badanych - u chłopców, którzy odbyli inicjację, ten wiek jest znacząco niższy. Może być to związane zarówno z czynnikami kulturowymi (różnicami w socjalizacji rodzajowej), jak i biologicznymi (większym poziomem napięcia seksualnego u chłopców).

Czynnikiem, który silnie różnicuje zachowania seksualne młodzieży, był także typ szkoły, do której uczęszczała badana młodzież. Młodzież ucząca się w LO częściej miała za sobą tylko przedinicjacyjne doświadczenia seksualne niż ucząca się w technikach i ZSZ, jednak uczniowie LO rzadziej niż uczniowie pozostałych typów szkół podjęli już współżycie seksualne. W przypadku dziewcząt inicjację seksualną częściej przeszły uczennice techników niż pozostałych typów szkół, w przypadku 
chłopców częściej odbyli inicjację seksualną uczniowie ZSZ. Rezultat ten jest zbieżny z wynikami badań Z. Izdebskiego zrealizowanych w 2004 roku na próbie uczniów drugich klas szkół ponadgimnazjalnych [14].

Wśród badanej młodzieży obserwowano, że inicjację seksualną częściej podejmowała młodzież posiadająca niższe wsparcie w rodzinie. Szczególnie było to widoczne w grupie chłopców. Należy zwrócić jednak uwagę na to, że zależność pomiędzy podejmowaniem aktywności seksualnej, w tym podjęciem współżycia seksualnego, a wsparciem społecznym nie ma charakteru bezpośredniego, ponieważ o ile użyta w badaniach skala pozwalała ocenić aktualne wsparcie rodziny, o tyle wiemy, że poczucie wsparcia nie ma charakteru statycznego i mogło być inne we wcześniejszych okresach życia badanej młodzieży. Znajduje to potwierdzenie w pracach innych autorów, którzy wykazują, że poziom odczuwanego wsparcia rodziców przez młodzież maleje wraz z wiekiem [34].

W prezentowanych analizach zachowania seksualne młodzieży wykazywały związek z zamożnością rodziny. Młodzież pochodząca z rodzin o niskim statusie materialnym rzadziej niż osoby pochodzące $\mathrm{z}$ rodzin o przeciętnym i wysokim statusie materialnym miała za sobą tylko przedinicjacyjne doświadczenia seksualne. W przypadku dziewcząt częściej miały za sobą inicjację seksualną osoby pochodzące $z$ rodzin o niskim statusie materialnym, w grupie chłopców zaś osoby pochodzące z rodzin zamożnych. Rezultat ten jest zbieżny z wynikami innych badań przytaczanych w tym opracowaniu.

Wyniki estymacji modelu regresji logistycznej pozwoliły wykazać, że w populacji chłopców w porównaniu z rówieśnikami, którzy nie mają za sobą żadnych doświadczeń seksualnych, czynnikiem ryzyka inicjacji seksualnej jest niskie wsparcie rodziny oraz wysoki poziom zamożności, natomiast czynnikiem chroniącym przed inicjacją uczęszczanie do liceum ogólnokształcącego lub technikum, natomiast $\mathrm{w}$ grupie dziewcząt czynnikiem chroniącym przed inicjacją seksualną jest uczęszczanie do liceum ogólnokształcącego, natomiast czynnikiem ryzyka zamieszkiwanie w dużym mieście.

Dojrzewanie oraz konfrontacja rodzących się potrzeb seksualnych z wymaganiami kulturowymi jest sytuacją trudną dla młodych ludzi, a sposób radzenia sobie z tą sytuacją warunkuje ich samopoczucie, jest ważnym wyznacznikiem zdrowia subiektywnego [35]. Zaprezentowane wyniki badań, duża skala podejmowania aktywności przedinicjacyjnej i inicjacji seksualnej przez młodzież upoważniają do tego, aby w sposób jednoznaczny sformułować wniosek o konieczności modyfikacji procesu socjalizacji seksualnej w rodzinie i szkole. Młodzieży potrzebne jest mądre wsparcie osób dorosłych. W tym kontekście należy kolejny raz uznać, że aktualny kształt edukacji i profilaktyki seksualnej w polskich szkołach, realizowanie programów zmierzających wyłącznie do zachowania całkowitej abstynencji seksualnej przez młodzież wydają się nieefektywne [36]. Szczególnie niepokoi skala aktywności seksualnej podejmowanej przez uczniów zasadniczych szkół zawodowych. W tym zakresie należy zrealizować zgłaszany od dawna postulat szczególnej intensyfikacji oddziaływań edukacyjnych i profilaktycznych w odniesieniu do tej kategorii osób. Niestety, dane podawane w Szkolnym Informatorze Oświatowym niezmiennie dowodzą, że to właśnie uczniowie tego typu szkół najmniej licznie uczęszczają na zajęcia wychowania do życia w rodzinie [37]. Wśród czynników rodzinnych wziętych pod uwagę w prezentowanych tu badaniach występuje zależność pomiędzy wsparciem społecznym w rodzinie a podejmowaniem aktywności seksualnej przez młodzież. Wskazuje to na konieczność uwzględniania tych różnic w prowadzonych działaniach z zakresu promocji zdrowia i profilaktyki zachowań ryzykownych adresowanych do dzieci i ich rodziców.

Na zakończenie warto podkreślić, iż w celu opracowania skutecznych programów edukacyjnych i profilaktycznych, mających na celu zapobieganie podejmowaniu zbyt wczesnej inicjacji seksualnej przez młodzież, konieczne jest stałe śledzenie uwarunkowań tych zachowań. Wymaga to realizacji dobrze zaprojektowanych badań ilościowych i jakościowych.

\section{Piśmiennictwo}

1. Woynarowska B. (red.), Edukacja zdrowotna. Podręcznik akademicki, PWN, Warszawa 2008.

2. Beisert M., Trud dorastania seksualnego, w: Beisert M. (red.), Seksualność w cyklu życia człowieka, Wydawnictwo Naukowe PWN, Warszawa 2006.

3. Oleszkiewicz A., Senejko A., Psychologia dorastania. Zmiany rozwojowe w okresie globalizacji, Wydawnictwo Naukowe PWN, Warszawa 2013.

4. Sokołowska M., Granice medycyny, Wiedza Powszechna, Warszawa 1980.

5. Regional Strategy on Sexual and Reproductive Health. Reproductive Health/Pregnancy Programme, WHO, Copenhagen 2001: 7.

6. Karta Praw Seksualnych i Reprodukcyjnych Międzynarodowej Federacji Planowanego Rodzicielstwa, Wizja 2000, IPPF, Towarzystwo Rozwoju Rodziny, Warszawa 2000.

7. Beisert M., Rozwojowa norma seksuologiczna jako kryterium oceny zachowań seksualnych dzieci i młodzieży, „Dziecko Krzywdzone” 2006; 16: 1-15.

8. Erikson E.H., Dzieciństwo i spoteczeństwo, Dom Wydawniczy „Rebis”, Poznań 2000.

9. Jankowiak B., Gulczyńska A., Wczesna inicjacja seksualna młodzieży - przyczyny i konsekwencje, „Kultura - Społeczeństwo - Edukacja" 2014, 1 (5): 171-187.

10. Beisert M. (red.), Seksualność człowieka w cyklu życia, Wydawnictwo Naukowe PWN, Warszawa 2006.

11. Izdebski Z., Rozwój seksualny, w: Woynarowska B., Kowalewska A., Izdebski Z., Komosińska K., Biomedyczne podstawy kształcenia $i$ wychowania, Wydawnictwo Naukowe PWN, Warszawa 2010.

12. Gasparski P., Zwiqzek doświadczeń z ocenami prawdopodobieństwa zagrożeń i aktywnościa profilaktyczna, w: Studenski R. (red.), Zachowanie się w sytuacji ryzyka, Katowice 2004.

13. Erikson E., Tożsamość a cykl życia, Zysk i S-ka, Poznań 2004. 
14. Izdebski Z., Seksualność Polaków na poczqtku XXI wieku. Studium badawcze, Wydawnictwo Uniwersytetu Jagiellońskiego, Kraków 2012.

15. Jaczewski A., Obuchowska I., Rozwój erotyczny, Wydawnictwa Szkolne i Pedagogiczne, Warszawa 1992.

16. Imacka J., Bulsa M., Ryzykowne zachowania seksualne młodzieży jako czynnik zwiększajacy ryzyko zakażenia chorobami przenoszonymi droga ptciowa, „Hygeia Public Health" 2012; 47: 3.

17. Wąż K., Socjalizacja seksualna i przemiany w obyczajowości seksualnej młodzieży, w: Izdebski Z., Niemiec T., Wąż K., (Zbyt)mtodzi rodzice, Wydawnictwo TRIO, Warszawa 2011.

18. Zawadzka A., Ten pierwszy raz. Konstruowanie heteroseksualności, Wydawnictwo Uniwersytetu Warszawskiego, Warszawa 2015.

19. Ramiro I., Windlin B., Nic Gabhainn S. et al., Gendered trends in early and very early sex and condom use in 20 European countries from 2002 to 2010, „European Journal of Public Health" 2015; 25 (suppl. 2): 65-68.

20. Woynarowska B., Szymańska M., Mazur J., Wiedza i przekonania o HIV/AIDS. Zachowania seksualne. Raport z badań wykonanych w 1998 r., Katedra Biomedycznych Podstaw Rozwoju i Wychowania Wydział Pedagogiczny UW, Warszawa 1999.

21. Mazur J., Małkowska-Szkutnik A. (red.), Wyniki badań HBSC 2010. Raport techniczny, Instytut Matki i Dziecka, Warszawa 2011.

22. Opinie i oczekiwania młodych dorostych (osiemnastolatków) oraz rodziców dzieci w wieku szkolnym wobec edukacji dotyczqcej rozwoju psychoseksualnego i seksualności. Raport z badania, Instytut Badań Edukacyjnych, Warszawa 2015.

23. Mazur J. (red.), Zdrowie i zachowania zdrowotne młodzieży szkolnej w Polsce na tle wybranych uwarunkowań socjodemograficznych. Wyniki badań HBSC 2014, Instytut Matki i Dziecka, Warszawa 2015.

24. Izdebski Z., Wiedza, przekonania o HIV/AIDS w spoteczeństwie polskim. Zachowania seksualne, Wydawnictwo Naukowe PWN, Warszawa 2000.

25. Woynarowska B., Tabak I., Czynniki ryzyka wczesnej inicjacji seksualnej, „Medycyna Wieku Rozwojowego” 2008; 2, część 2: 541-557.

26. Madkour A.S., Farhat T., Halpern C.T., Godeau E., Gabhainn S., Early adolescent sexual initiation as a problem behavior: A comparative study of five nations, „Journal of Adolescent Health" 2010; 47: 389-398.

27. Shoveller J.A., Johnson J.L., Langille D.B. et al., Sociocultural influences on young people's sexual development, „Social Science \& Medicine” 2004; 59: 473-487.

28. Berne L.A., Huberman B.K., Lesson learned. European approaches to adolescent sexual behavior and sexuality, „Journal of Sex Education and Therapy” 2000; 25: 189199.

29. Valle A.-K., Roysamb E., Sundby J., Klepp K.I., Parental social position, body image, and other psychosocial determinants and first sexual intercourse among 15- and 16-year olds, „Adolescence” 2009; 44 (174): 479-498.

30. Kogan S.M., Yu T., Allen K.A., Pocock A.M., Brody G.H., Pathways from racial discrimination to multiple sexual partners among male African American adolescents, „Psychology of Men \& Masculinity" 2014; 8: 1-11.

31. Harden P.K., Genetic influences on adolescent sexual behavior: Why genes matter for environmentally oriented researchers? „Psychological Bulletin” 2014; 2: 434-465.

32. Currie C., Inchley J., Molcho M. et al., Health Behaviour in Schoolaged Children (HBSC) Study Protocol: Background, Methodology and Mandatory Items for the 2013/14 Survey, St. Andrews University, Scotland, UK 2014.

33. Obuchowska I., Adolescencja, w: Harwas-Napierała B., Trempała J. (red.), Psychologia rozwoju człowieka, t. II, PWN, Warszawa 2003.

34. Małkowska A., Wsparcie spoteczne, w: Mazur J. (red.), Zdrowie i zachowania zdrowotne młodzieży szkolnej w Polsce na tle wybranych uwarunkowań socjodemograficznych. Wyniki badań HBSC 2014, Instytut Matki i Dziecka, Warszawa 2015.

35. Oblacińska A., Woynarowska B. (red.), Zdrowie subiektywne, zadowolenie z życia i zachowania zdrowotne uczniów szkót ponadgimnazjalnych $w$ Polsce $w$ kontekście czynników psychospołecznych i ekonomicznych, Instytut Matki i Dziecka, Warszawa 2006.

36. Izdebski Z., Wąż K., Edukacja seksualna. Potrzeba, oczekiwania społeczne, realizacja, „Edukacja. Studia. Badania. Innowacje" 2011; 1: 47-60.

37. Uczestnictwo uczniów $w$ zajęciach wychowania do życia w rodzinie. Dane za rok szkolny 2007/2008 wg stanu na 31 marca 2008 r., w: Szkolny Informator Oświatowy, Oświata $i$ wychowanie w roku szkolnym 2007/2008, Główny Urząd Statystyczny, Warszawa 2008. 